\title{
An Empirical Investigation of the Relationship between Store Attributes and Customer Satisfaction: A Retail Operations Perspective
}

\author{
Yash Daultani \\ Operations Management Group, Indian Institute of Management Lucknow, \\ Prabandh Nagar, Lucknow - 226013, India \\ Email: yash.daultani@gmail.com (Corresponding Author)
}

Kshitij Goyal

Kalicharan Darshanlal Jewellers, Birla Jewels Limited, Gwalior - 474006, India

Email: kshtjgoyal06@gmail.com

Saurabh Pratap

Department of Mechanical Engineering, Indian Institute of Technology (BHU), Varanasi - 221005, India

Email: s.pratapiitkgp@gmail.com

\begin{abstract}
The purpose of this study is to identify key retail store attributes that impact customer satisfaction. The conceptual model is developed with the help of extant literature and expert opinion. The study analyzes the relationship among the store attributes, customer satisfaction, advocacy, and repurchase intention to provide operational insights to retail store managers concerning key store attributes. In particular, jewellery stores in India are selected for this research investigation. The data from jewellery stores and customers located in the Gwalior district is collected using the convenience sampling. The partial least squares-structural equation modeling (PLS-SEM) method is used for model validation and data analysis. The results reveal that the store-related attributes, product-related attributes, and service qualityrelated attributes have a positive influence over customer satisfaction. In these three attribute categories, the most sought factors by consumers were store layout $\&$ ambience, product durability, and overall assistance, respectively. Further, the customer satisfaction is found to affect advocacy and repurchase intention. The study suggests that jewellery store managers should focus on managing the select store attributes identified in this study to improve customer satisfaction, advocacy, and repurchase intentions. Though the study is conducted in the context of Indian jewellery stores, the insights are equally useful and explorable in other retail stores situated at diverse locations.
\end{abstract}

Keywords: retail, retail operations, quality, customer satisfaction, store attributes, advocacy, jewellery stores

\section{INTRODUCTION}

Retail is generally defined as the activities which include selling of goods or services directly to the end consumer or the final customer for their personal use through shops, personal selling, door-to-door selling, markets, over the internet etc. Indian retail market is recognized as one of the biggest and fast-growing markets in the world. The increased urbanization and higher income levels have increased consumer demand substantially, which makes the Indian market as quite attractive. With the growth in the Indian economy, consumers' behavior is also changing, as their spending is taking modern style influenced by psychological variables. Therefore, it is becoming essential for retailers and store managers to understand key store attributes and factors, which may influence customer satisfaction and loyalty. Some of the significant factors which consumers look for are - service and product quality, experience, convenience, and value-added services etc.

The Indian Gems and Jewellery sector is one of the crucial industries contributing to the Indian economy. The Jewellery industry contribution accounts for around 7\% of the country's GDP and $15 \%$ of India's total merchandise exports (ibef.org). The Jewellery industry employs 4.64 million workers. The Indian gems and jewellery sector contribute $29 \%$ to global jewellery consumption. It is a home for more than 300,000 players, with the majority being small players. Due to the adoption of the western lifestyle, the gems and jewellery sector is witnessing drastic changes in customer preferences (Maheswari and Balaji, 2017). Customers are becoming more and more demanding and aware. They are seeking more and more designs and varieties. These evolving customer needs are well catered by the branded Jewellers when compared to the local unorganized jewelers. Moreover, jewellery is seen as an investment and status symbol in India. The increase in the per capita income has led to an increase in jewellery sales. Also, awareness regarding the hallmark gold jewellery is increasing in Indian customers. Recently, the Indian government has announced to make the hallmarking of gold jewellery and artifacts mandatory across the country, starting 
from January 2021. The hallmarking is supposed to ensure quality and prevent the malpractices in the industry.

The growth in this industry is contributed mainly to the entry and development of the brands and large retailers, which are guiding the local players towards organized retailing and growth opportunities (Krishnan, 2019). The organized and branded jewellery stores can satisfy the evolving consumer needs by providing a vast variety in terms of product design, a pleasing shopping experience, and good after-sales services. Product variety has potential connections with business conditions and market competition (Huddiniah and Mahendrawathi, 2019). The market competition has increased with the entry of brands like Tanishq, Kalyan, PC jewelers, Malabar, Joyallukas, Bjewels etc. Branded stores are changing the market while providing fierce competition to local jewelers. These brands are making tremendous efforts to understand Indian consumer to be able to satisfy the needs of the heterogeneous customer base.

Studies show that Indian consumers are starting to prefer large retail stores as compared to small and local stores, because of the factors like brand image, cleanliness, promotional offers, etc. (Rai and Gopal, 2017). Customer attitudes are positively linked to the convenience of the store, store location, staff attitude, and well-trained staff (Yuen et al., 2010). The concept of one-stop shopping has also attracted many customers. Now customers like all of their needs to be fulfilled at a single store. The young population and working professionals prefer to visit large brand outlets and shopping malls, whereas the elderly population prefers to visits shops where they know shop owners from their past purchases. We believe that many attributes relevant to other retails concepts will also be relevant in the case of jewellery stores. Indian customers are price sensitive and want maximum value from the products and services they consume. They are highly demanding, and it is becoming imperative for retailers to identify and understand these customers' needs to sustain their business. In the present competitive market, each organization is trying to attract more and more customers to increase their market share, while trying to minimize the risk across different functional divisions (Daultani et al., 2019). This has also resulted in the increased bargaining power of the customers. In today's scenario, retailers are not limiting themselves to just selling the product, but also focusing on after-sales services and post-purchase connect with customers. For retaining and motivating the customer for future purchases, retailers need to understand the unexpressed customer needs, the factors influencing those needs, and to create an overall service experience through the identified customer touch-points (Ghosh et al., 2010; Yuen et al., 2010). For jewellery industry, customer relationship management (CRM) is crucial. Retailers these days are trying to maintain customer relationships through different ways like membership cards, festival offers, gifts, coupons etc. (Noronha, 2009). To address the aforementioned issues and challenges, this study attempts to investigate the relationship between jewellery store attributes and customer satisfaction. Also, the effect of the extent of customer satisfaction on repurchase intentions and advocacy are explored.

The next section presents the literature review. Section 3 summarizes the model variables, hypotheses development, and presents the conceptual model. Section 4 presents the methodology in detail. Analysis and results are discussed in section 5. The last section concludes the work and presents managerial insights along with future research directions.

\section{LITERATURE REVIEW}

The store image is one of the most critical determinants of the retail patronage behavior of the consumers. The more favorable is store image, the more chances are there that consumers will buy and shop from that store (Bloemer \& Ruyter, 1998). The store attributes affect the choice of the customer for selecting the store for shopping. Based on the store attributes, the store image is developed in the mind of the customer, which helps them to choose the store (Thomas, 2013). The store attributes affect customer behavior at every shopping stage: pre-purchase, during purchasing, and post purchasing. The store attributes add value to the product or service offered by the retailer. The store attributes impact customer satisfaction, which leads to retail patronage behavior of the customers. The store attributes vary with different types of retail store formats and also with the products or merchandise they are selling. A store attribute important for a grocery store may not be that important for an apparel store. A retail store in a shopping complex or shopping mall may have different store attributes as compared to a retail store located in the main street of the city. Also, the importance of the store attributes varies from customer to customer. Broadly, the literature analysis of four areas is presented below namely, customer satisfaction, store attributes, advocacy, and repurchase intention.

\subsection{Customer Satisfaction}

Customer satisfaction can be defined as the positive feeling or effect, which is based on the comparison between the customers' perceived level of offering or outcomes and the expected level of offerings or outcomes. Nair (2018) explored the relationship between patronage intentions and store attributes while considering customer satisfaction as a mediator. The study concluded that lifestyle does not qualify as a moderator for these relationships. In the case of activewear specialty stores, Chang et al. (2015) found store attributes atmosphere and sales employees to have a positive influence on consumer satisfaction. Yi and La (2004) conducted a study to differentiate between low-loyalty and high-loyalty customers with reference to the effect of customer satisfaction on repurchase intention. Sivadas and Baker-Prewitt (2000) conducted a study to find out the relationship between service quality, customer satisfaction, and store attributes for a retail department store. Service quality was found out as an important factor that influences consumer satisfaction; however, no evidence on consumer loyalty was established in their study. Also, service quality should be seen from the perspective of customers (Venkatesh, 2015; Uvet, 2020).

\subsection{Store Attributes}

The store attributes can be defined as the factors or the environment of the retail store, which affect and influence consumer behavior and desire to purchase from a specific retail store. The store attributes have been classified in different ways by several researchers (Basu et al. 2014, Prasad and Aryasri, 2011). Store attributes can also be understood as marketing-mix variables, which influence 
customer buying intentions and patronage behavior. Based on the context of the store, store attributes can be broadly classified as product-related attributes (Baker et al. 2002, Dhar et al. 2001, Akbar, 2014); service quality-related attributes (Akbar, 2014, Sinha and Banerjee, 2004, Prasad and Aryasri, 2011); and store related attributes (Das, 2014, Ali and Amin, 2014, Seock and Bailey, 2009). This study utilizes this store attribute classification in three dimensions, namely, product-related attributes, service quality-related attributes, and store-related attributes, as derived from literature and considering expert opinion comprising of toplevel branded jewellery stores managers.

Shopping Convenience affects customer satisfaction the most, followed by other factors like Pricing, Product Convenience, and Employee Service (Patel and Desai, 2013). Customer service, gold's liquidity, television advertisement, certification of jewellery are some of the major factors which influence the selection of jewellery shops (Thomas, 2013). Jhamb and Kiran (2012) indicated that modern retail formats are attracting customers due to quality, variety, and other factors such as security, parking facility, and assistance through trained sales personnel. In the case of hypermarket store selection, the main factors driving customer preferences are product quality, assortment, store space, operating hours, cleanliness, and introduction of new products (Aldousari and El-Sayed, 2017).

\subsection{Advocacy}

When the existing customers of a firm talk positively about the company's products and services and recommend other people to use them is known as advocacy. Generally, advocacy leads to the generation of the promoters of the brand or company, which influences other people to purchase from the same company, brand, or store. The customers who are highly satisfied with the products and services of the brand/store/company are expected to exhibit this behavior. The social media review and service operations have a positive and significant impact on customer satisfaction (Ramanathan et al., 2017). The two components of commitment, namely affective commitment $\&$ continuance commitment, fully mediate the relationship between brand satisfaction and both repurchase intentions and advocacy intentions (Fullerton, 2005).

\subsection{Repurchase Intention}

The repurchase intention can be defined as the chance of customers revisiting and making repeat purchases from the same store in the future. Satisfied customers are more likely to revisit, recommend, and repurchase the offerings from the same store. Chang et al. (2015) tried to investigate these issues in the case of activewear specialty stores. They found that sales employees and store atmosphere attributes affect consumer satisfaction positively. This, in turn, is found to have a direct impact on word of mouth (WOM) and repatronage intentions. On similar lines, Nair (2018) also found satisfaction to act as a mediator in the relationship between store attributes and patronage intention.

\section{MODEL DEVELOPMENT}

Various studies have been conducted to identify product, store, and service-related attributes and customer satisfaction. The previous studies were done in activewear, groceries, food, and fashion industry, but no study has been done on jewellery stores in particular. Different sectors, such as food industry in particular have diverse challenges such as perishability (Prajapati et al., 2020). However, despite the sectoral differences, issues that are common to different sectors should be investigated for seeking similar solutions (Daultani et al., 2016). In the jewellery sector, only customer behavior is studied so far, and studies pertaining to customer satisfaction are scant. The variables identified in this study for store attributes with respect to jewellery stores to examine its impact over repurchase intention and advocacy are not studied together. To fulfill the above identified research gaps, the following variables are identified from retail literature for investigation. Further, these variables are refined using expert opinion for jewellery stores. The relevant literature pertaining to model variables for jewellery stores are summarized in Table 1.

The literature review shows that the link between the store attributes, customer satisfaction, advocacy, and repurchase intention is needed to be investigated. Various studies have been conducted earlier to study these constructs independently, but these constructs have not been studied together in the context of Jewellery stores. To investigate these issues, this study proposed the conceptual model, as shown in Figure 1.

Table 1 Model variables

\begin{tabular}{l|l}
\hline \multicolumn{1}{c|}{ Variable } & \multicolumn{1}{c}{ Relevant Literature } \\
\hline Customer Satisfaction & Söderlund et al. (2014), Akbar (2014), Shi et al. (2016) \\
Repurchase Intention & Jani and Han (2014), Das (2014), Ali and Amin (2014), Söderlund et al. (2014), Akbar (2014), \\
& Fullerton (2005) \\
Advocacy & Fullerton and Taylor (2002), Fullerton (2005) \\
Store Attributes & Basu et al. (2014), Prasad and Aryasri (2011) \\
Product Quality & Baker et al. (2002), Dhar et al. (2001), Akbar (2014) \\
Product Variety & Dhar et al. (1997), Carpenter and Moore (2006) \\
Certification & Thomas (2013) \\
Price and Offers & Desai and Talukdar (2003), Dhar et al. (1997), Akbar (2014), Mittal et al. (2008) \\
\hline
\end{tabular}




\begin{tabular}{|c|c|}
\hline Variable & Relevant Literature \\
\hline Service Quality & Akbar (2014), Sinha and Banerjee (2004), Prasad and Aryasri (2011) \\
\hline Staff Attitude & Schiffman et al. (2000), Chang et al. (2015), Ranjbari et al. (2015) \\
\hline Individual Attention & Patel and Desai (2013), Ranjbari et al. (2015) \\
\hline Exchange and Buyback Policies & Mittal et al. (2008), Thomas (2013) \\
\hline Flexibility in Payment Mode & Patel and Desai (2013), Aldousari and El-Sayed (2017) \\
\hline Store environment / Ambience & Das (2014), Ali and Amin (2014), Seock and Bailey (2009), Chang et al. (2015) \\
\hline Location & $\begin{array}{l}\text { Pan and Zinkhan (2006), Sinha and Banerjee (2004), Prasad and Aryasri (2011), Barsing et al. } \\
\text { (2018) }\end{array}$ \\
\hline Parking Space & Patel and Desai (2013), Aldousari and El-Sayed (2017) \\
\hline Store Image & Das (2014), Koo (2003) \\
\hline Word of Mouth & Shi et al. (2016) \\
\hline
\end{tabular}

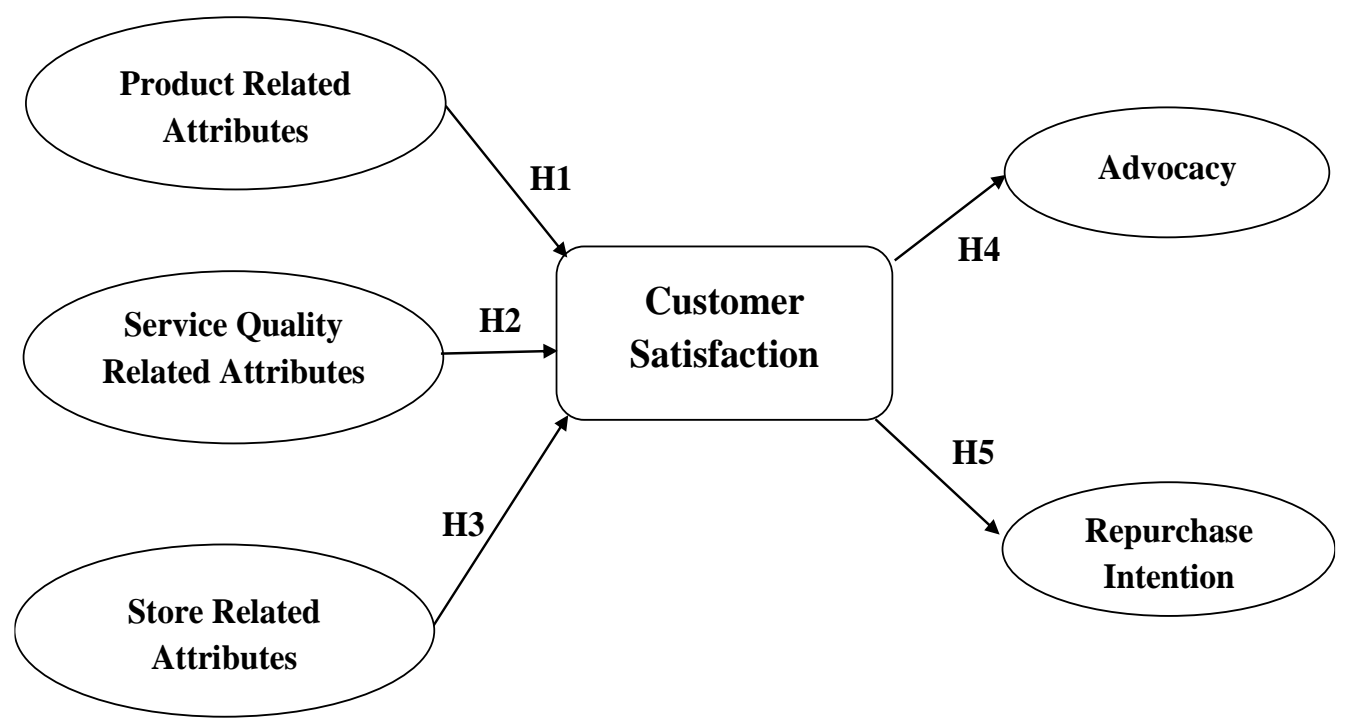

Figure 1. The conceptual model

The following hypotheses are formulated for the study.

H1: Customer satisfaction will be positively influenced by product-related attributes of a jewellery store.

H2: Customer satisfaction will be positively influenced by service quality-related attributes of a jewellery store.

H3: Customer satisfaction will be positively influenced by store-related attributes of a jewellery store.

H4: Advocacy will be positively influenced by customer satisfaction.

H5: Repurchase Intention will be positively influenced by customer satisfaction.

\section{METHODOLOGY}

This study adopts the non-probability sampling technique. Convenient sampling technique is used as the number of customers purchasing the jewellery are less than other daily consumable products. Also, customers in jewellery shops try to avoid giving responses to the survey, due to the fear of income disclosure. The responses were collected through the questionnaire containing 17 questions from the customers in the jewellery shops. Data is collected from jewellery stores located in Gwalior district which covers an area of around 4,500 square kilometers. The data is collected through offline and online channels. The measurement items were drawn from the previous research studies to reflect the context of the study. As suggested by experts, some items were adapted and changed to match the context of the study. The questionnaire was developed in two sections. The first section captured the demographic information of the customer like name, gender, marital status, age, and contact details. The second section captured the responses of the customer for the effect of the different store attributes on their satisfaction level, thus on advocacy and repurchase intention. All items are rated on 5 points Likert scale ranging from 1 (strongly disagree) to 5 (strongly agree). The summary of the research approach is as follows. 
- Data reliability is checked using SPSS by Cronbach's $\alpha$.

- The collected data were analyzed through SPSS for basic descriptive statistics.

- The conceptual framework was developed by the partial least square model using SmartPLS 2.0 software.

- SmartPLS 2.0 is used for analyzing the measurement model and the structural model. The software provides structural model estimates, construct validity, the statistical significance of factor loadings and path coefficients.

- To check the construct validity, convergent validity, and discriminant validity; confirmatory factor analysis (CFA) is conducted.

- The hypothesis testing or the structural model was tested using the t-statistic of the paths.

The questionnaire was circulated to 210 customers through both offline and online channel, and a total of 147 customer responses was received. Out of 147 responses, only 131 questionnaires were completed filled, and other remaining were rejected. This yields a response rate of $62.3 \%$. The reliability of the questionnaire is checked by Cronbach's $\alpha$. The value obtained was 0.954 , which is above 0.7 hence acceptable. The basic demographic data such as Age, Gender, and Marital status were collected from the customer to get better insights regarding the customers. The age of the customers was ranged from 18 years to 57 years. The Descriptive statistics show that out of 131 respondents, 82 are male $(62.6 \%)$, and 49 are female $(37.4 \%)$. The 67 of the total 131 respondents are unmarried, which accounts for $51.1 \%$ of the total, and the remaining 64 are married, which accounts for $48.9 \%$ of the total sample.

\section{ANALYSIS AND RESULTS}

\subsection{Measurement Model}

In the first stage, the model is encoded using the SmartPLS2.0. This is the measurement model that contains the items and the corresponding constructs with latent constructs. Figure 2 shows the PLS-SEM model, which shows the factor loadings of the items, $\mathrm{R}^{2}$ value, and Standardized $\beta$ Coefficients of the paths. The construct validity of the measurement model is tested through the convergent validity, and discriminant validity. Further, the confirmatory factor analysis (CFA) is conducted. For convergent validity, Fornell and Larcker (1981) suggested that the value of the outer loadings and AVE (Average Variance Extracted) should be greater than 0.5. From Table 2, we can see that value of AVE ranges from 0.58-1.0. Table 3 shows that the outer factor loading of the only SRA3 is less than 0.5 , so this item is less influential while all other items are having outer factor loading greater than 0.5 .

The discriminant validity can be checked by the crossloading tabulations that check the loadings of the items on other constructs. It can be seen from Table 4 that each item of a construct has maximum loading to the corresponding construct only. Hence, it can be inferred that each item measures the effects for which it has been designed for. In cross-loadings also, we can see that SRA3 has a loading of less than 0.5 , but it is greater than the loadings of SRA3 for other constructs. For the benefit of the readers, Table 4 also presents the brief description of all model variables.

The internal consistency of the constructs can be checked by the Composite Reliability (CR) and Cronbach's $\alpha$. The values of both should be greater than 0.7 . As we can see from Table 2, the value of composite reliability ranges from 0.84 to 1.0 , and the value of Cronbach's $\alpha$ ranges from 0.75 to 1.0 , hence we can say that there is internal consistency in the model. From all the above values calculated from the CFA, it is concluded that the model is having good construct validity and reliability.

\subsection{Structural Model}

In the second stage, hypotheses testing is performed by developing an SEM using PLS path models. The path analysis checks whether the relationships between the different constructs is significant or not. R Square explains the percentage of the variance explained by the exogenous constructs in endogenous constructs. From Figure 2, we can see that Product-Related Attributes, Service Quality-Related Attributes, and Store-Related Attributes are exogenous constructs for customer satisfaction, and customer satisfaction is an exogenous construct for Advocacy and Repurchase intention. Customer satisfaction, Advocacy, and Repurchase Intention are endogenous constructs in the model. The $\mathrm{R}^{2}$ for Customer Satisfaction is found to be 0.72 , which means $72 \%$ of the variance in customer satisfaction is explained by the Product-Related Attributes, Service Quality-Related Attributes, and Store-Related Attributes. $\mathrm{R}^{2}$ for advocacy is 0.56 , which means $56 \%$ of the variance is explained by customer satisfaction, and $\mathrm{R}^{2}$ for Repurchase Intention is 0.42 , which means $42 \%$ of the variance in Repurchase Intention is explained by the customer satisfaction. 


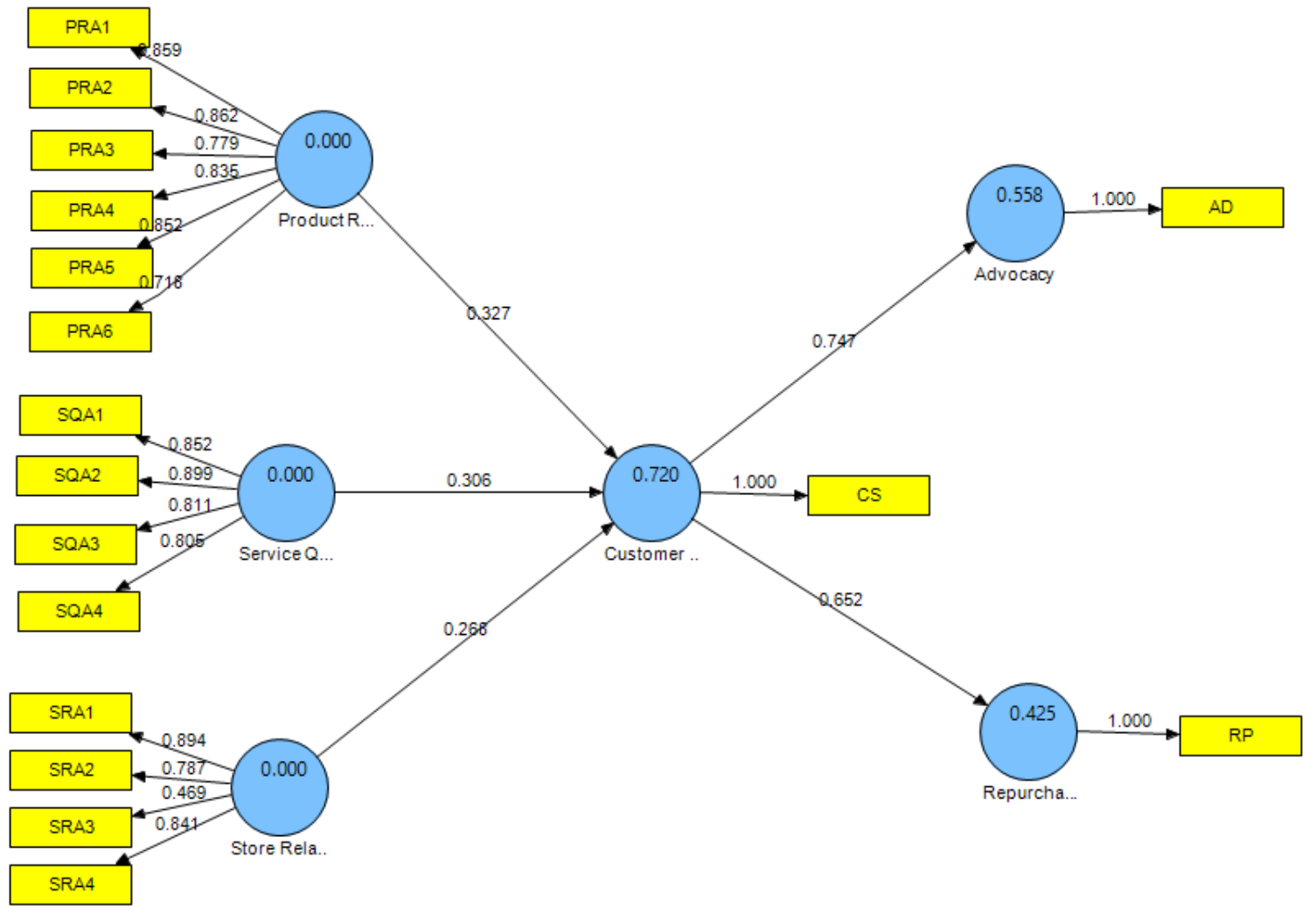

Figure 2. PLS-SEM model with factor loadings

Table 2 AVE and Cronbach's Alpha

\begin{tabular}{lccc}
\hline & AVE & Composite Reliability & Cronbach's Alpha \\
\hline Advocacy & 1.000000 & 1.000000 & 1.000000 \\
Customer Satisfaction & 1.000000 & 1.000000 & 1.000000 \\
Product Related Attributes & 0.670859 & 0.924119 & 0.900948 \\
Repurchase Intention & 1.000000 & 1.000000 & 1.000000 \\
Service Quality Related Attributes & 0.710127 & 0.907233 & 0.863414 \\
Store Related Attributes & 0.586787 & 0.844138 & 0.754320 \\
\hline
\end{tabular}

Table 3 Outer loadings

\begin{tabular}{|c|c|c|c|c|c|c|}
\hline & Advocacy & $\begin{array}{l}\text { Customer } \\
\text { Satisfaction }\end{array}$ & $\begin{array}{l}\text { Product-Related } \\
\text { Attributes }\end{array}$ & $\begin{array}{l}\text { Repurchase } \\
\text { Intention }\end{array}$ & $\begin{array}{c}\text { Service Quality-Related } \\
\text { Attributes }\end{array}$ & $\begin{array}{c}\text { Store-Related } \\
\text { Attributes }\end{array}$ \\
\hline$A D$ & 1.000000 & & & & & \\
\hline CS & & 1.000000 & & & & \\
\hline PRA1 & & & 0.859119 & & & \\
\hline PRA2 & & & 0.862309 & & & \\
\hline PRA3 & & & 0.778509 & & & \\
\hline PRA4 & & & 0.834685 & & & \\
\hline PRA5 & & & 0.851746 & & & \\
\hline
\end{tabular}


Table 3 Outer loadings (cont')

\begin{tabular}{|c|c|c|c|c|c|c|}
\hline & Advocacy & $\begin{array}{l}\text { Customer } \\
\text { Satisfaction }\end{array}$ & $\begin{array}{l}\text { Product-Related } \\
\text { Attributes }\end{array}$ & $\begin{array}{l}\text { Repurchase } \\
\text { Intention }\end{array}$ & $\begin{array}{c}\text { Service Quality-Related } \\
\text { Attributes }\end{array}$ & $\begin{array}{c}\text { Store-Related } \\
\text { Attributes }\end{array}$ \\
\hline PRA6 & & & 0.717804 & & & \\
\hline $\mathrm{RP}$ & & & & 1.000000 & & \\
\hline SQA1 & & & & & 0.852289 & \\
\hline SQA2 & & & & & 0.898745 & \\
\hline SQA3 & & & & & 0.811243 & \\
\hline SQA4 & & & & & 0.805144 & \\
\hline SRA1 & & & & & & 0.894378 \\
\hline SRA2 & & & & & & 0.787198 \\
\hline SRA3 & & & & & & 0.469424 \\
\hline SRA4 & & & & & & 0.840950 \\
\hline
\end{tabular}

Table 4 Cross loadings

\begin{tabular}{lccccccc}
\hline \multicolumn{1}{c}{ Model Variable } & Notation & $\begin{array}{c}\text { Advocacy } \\
\text { (AD) }\end{array}$ & $\begin{array}{c}\text { Customer } \\
\text { Satisfaction } \\
\text { (CS) }\end{array}$ & $\begin{array}{c}\text { Product- } \\
\text { Related } \\
\text { Attributes } \\
\text { (PRA) }\end{array}$ & $\begin{array}{c}\text { Repurchase } \\
\text { Intention } \\
\text { (RP) }\end{array}$ & $\begin{array}{c}\text { Service Quality- } \\
\text { Related Attributes } \\
\text { (SQA) }\end{array}$ & $\begin{array}{c}\text { Store- } \\
\text { Related } \\
\text { Attributes } \\
\text { (SRA) }\end{array}$ \\
\hline Advocacy & AD & 1 & 0.746788 & 0.72475 & 0.670606 & 0.730267 & 0.692604 \\
\hline Customer Satisfaction & CS & 0.746788 & 1 & 0.801682 & 0.651877 & 0.816001 & 0.775168 \\
\hline Purity & PRA1 & 0.60508 & 0.658893 & 0.859119 & 0.632486 & 0.724238 & 0.652612 \\
Product durability & PRA2 & 0.6341 & 0.70904 & 0.862309 & 0.594797 & 0.727363 & 0.644776 \\
Variety & PRA3 & 0.537522 & 0.621792 & 0.778509 & 0.513832 & 0.647416 & 0.566828 \\
Certification & PRA4 & 0.596163 & 0.686888 & 0.834685 & 0.671674 & 0.756802 & 0.651791 \\
Pricing & PRA5 & 0.660457 & 0.705303 & 0.851746 & 0.600663 & 0.799143 & 0.667815 \\
Making charges & PRA6 & 0.515195 & 0.539291 & 0.717804 & 0.538302 & 0.636888 & 0.601035 \\
\hline Repurchase Intention & RP & 0.670606 & 0.651877 & 0.72401 & 1 & 0.701684 & 0.795947 \\
\hline Staff knowledge & SQA1 & 0.574275 & 0.616176 & 0.698083 & 0.618883 & 0.852289 & 0.70456 \\
Overall assistance & SQA2 & 0.670573 & 0.788867 & 0.792239 & 0.595168 & 0.898745 & 0.758218 \\
Buyback \& exchange & SQA3 & 0.573691 & 0.656172 & 0.729879 & 0.573076 & 0.811243 & 0.689801 \\
Payments & SQA4 & 0.633779 & 0.670264 & 0.724544 & 0.583777 & 0.805144 & 0.651529 \\
\hline Layout \& ambience & SRA1 & 0.602498 & 0.69999 & 0.671727 & 0.718316 & 0.728564 & 0.894378 \\
Store location & SRA2 & 0.461921 & 0.518717 & 0.522171 & 0.578842 & 0.602589 & 0.787198 \\
Parking & SRA3 & 0.311499 & 0.275738 & 0.308465 & 0.275571 & 0.357691 & 0.469424 \\
Goodwill & SRA4 & 0.661705 & 0.742247 & 0.742606 & 0.733064 & 0.766169 & 0.84095 \\
\hline
\end{tabular}

Figure 3 shows the PLS-SEM model, which shows different paths of the model along with the t-values of the associated paths. While Figure 2 shows the value of standardized path coefficients $(\beta)$ of the respective paths, Figure 3 shows the t-value for all the relationships. The same values are presented in Table 5. The path coefficients are significant, or we can say the hypothesis is accepted if the tvalue is greater than 1.96 at a $95 \%$ confidence level.

Table 5 indicates that Product-Related Attributes $(\beta=0.327 ; \quad$ t-value $=2.460), \quad$ Service Quality-Related Attributes $(\beta=0.306 ; \mathrm{t}$-value $=2.297)$ and Store-Related Attributes $(\beta=0.268 ; \mathrm{t}$-value $=2.190)$ have positive and significant effect on Customer Satisfaction. Thus, hypothesis $\mathrm{H} 1, \mathrm{H} 2$, and $\mathrm{H} 3$ are supported. The path Customer Satisfaction and Advocacy $(\beta=0.747 ; \mathrm{t}$-value $=13.653)$ is significant, and customer satisfaction has a positive effect on advocacy. The hypothesis H4 is supported. The path Customer Satisfaction and Repurchase Intention $(\beta=0.651$; $t$ value $=6.483)$ is significant, and customer satisfaction has a positive effect on repurchase intention. The hypothesis H5 is supported. Hence, it is inferred that product-related, service quality-related, and store related attributes positively affect customer satisfaction, and customer satisfaction in turn positively leads to advocacy and repurchase intention. 


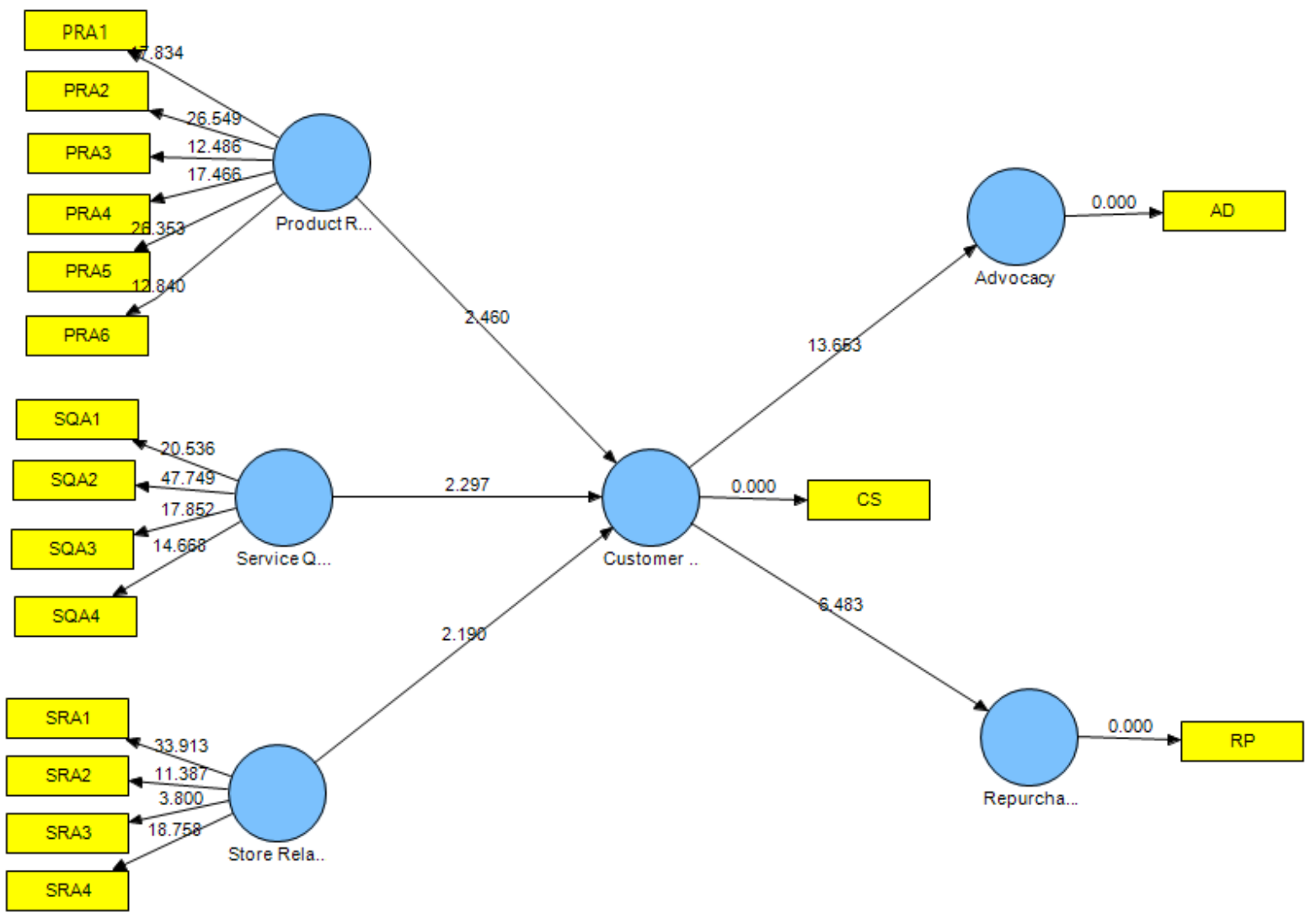

Figure 3. PLS-SEM significance

Table 5 Structural model estimates (95\% confidence level)

\begin{tabular}{lccc}
\multicolumn{1}{c}{ PATH } & $\beta$ Coefficients & T Statistics & Result \\
\hline H1: Product-Related Attributes $\rightarrow$ Customer Satisfaction & 0.326895 & 2.460473 & Yes \\
H2: Service Quality-Related Attributes $\rightarrow$ Customer Satisfaction & 0.306255 & 2.297330 & Yes \\
H3: Store Related Attributes $\rightarrow$ Customer Satisfaction & 0.268172 & 2.190151 & Yes \\
H4: Customer Satisfaction $\rightarrow$ Advocacy & 0.746788 & 13.653273 & Yes \\
H5: Customer Satisfaction $\rightarrow$ Repurchase Intention & 0.651877 & 6.483307 & Yes \\
\hline
\end{tabular}

\section{CONCLUSIONS AND FUTURE RESEARCH DIRECTIONS}

This study is conducted to examine the relationships between store attributes, customer satisfaction, advocacy, and repurchase intention simultaneously in the context of Jewellery stores in India. The data from jewellery stores and customers located in the Gwalior district (India) is collected using the convenience sampling. The partial least squaresstructural equation modeling (PLS-SEM) method is used for model validation and data analysis. The results reveal that the store-related attributes, product-related attributes, and service quality-related attributes have a positive influence over customer satisfaction. This is opposed to the findings by Chang et al. (2015) in the case of activewear specialty stores, where the impact of store-related attributes on customer satisfaction was found insignificant. Results also confirm that the positive customer satisfaction will lead to advocacy and repurchase intention for jewellery stores, which was not established in the jewellery stores literature so far.

These findings can help the jewellery store owners and store managers to learn and apply the outcomes of this study to meet the expectation levels of their customers and satisfy them. In the case of product-related attributes, more importance should be given to the purity of jewellery, its durability, and the gold rates charged by the jeweller. The purity of the jewellery is one essential quality criteria, which is determined by other factors like the gold rate, buyback policy, and the value of the jewellery. The durability of the jewellery leads to its functional use, and the gold rate charges have a direct impact over the price charged to the customer. In the case of service quality-related attributes, it is found that sales staff dressing, product knowledge, skill-set, and attitude should be given extreme importance. In jewellery stores, the customer and sales personnel interaction play a 
vital role. The salesperson should be able to understand customer needs and should be willing to help them. They should have proper skill-sets and product knowledge to assist the customer in the buying process. This study found that for store-related attributes, attractive shopping experience and positive store image are essential for customer satisfaction. In contrast, the availability of parking space is least important for the Indian customer. The jeweller should engage the customer in the buying process and should create an engaging shopping experience for the customer, which will lead to customer satisfaction. The store image which can also be interpreted as goodwill and the reputation of the store plays an important role increasing the customer satisfaction, as in case of jewellery store customer prefers to visit the store with good store image. Results also confirm that positive customer satisfaction leads to advocacy and repurchase intention. When the customers are satisfied with a store, they advocate the store and also spread positive WOM. Satisfied customers also patronize the store and visit the same store for their future purchases. These days with the influence of ICT and social media, the electronic word of mouth (e-WOM) is becoming more influential. These results are quite crucial for existing as well as MNCs, who are looking for entering in jewellery market in India after relaxed foreign direct investment (FDI) rules.

Though the study is conducted in the context of Indian jewellery stores, the insights are equally useful and explorable in other retail stores situated at diverse locations. Future researchers can take few other factors into consideration, such as brand loyalty, image, service innovation (Truong et al., 2020) and service recovery (Kandulapati and Bellamkonda, 2020) in case they need to revisit the findings in the context of international brand stores. Customer preferences change with different geographical areas; therefore, a study including new geographical areas, may reveal new insights. The moderation effect of different demographic factors might also be explored to gain new insights into customer expectations and behavior.

\section{ACKNOWLEDGMENT}

The authors would like to thank the Editor in Chief and anonymous reviewers for their constructive comments that helped in improving the manuscript significantly.

\section{REFERENCES}

Akbar, M.M. (2014). A causal study on the antecedents of retail shoppers' repatronage intention. European Journal of Business and Management, 6(4), pp.8-21.

Aldousari, A.A. and El-Sayed, I.M. (2017). Factors influencing consumers' patronage intentions in Kuwait. Journal of Business and Retail Management Research, 11(3), pp.144-153.

Ali, F. and Amin, M. (2014). The influence of physical environment on emotions, customer satisfaction and behavioural intentions in Chinese resort hotel industry. Journal for Global Business Advancement, 7(3), pp.249-266.

Baker, J., Parasuraman, A., Grewal, D. and Voss, G.B. (2002). The influence of multiple store environment cues on perceived merchandise value and patronage intentions. Journal of Marketing, 66(2), pp.120-141.

Barsing, P., Daultani, Y., Vaidya, O. S., \& Kumar, S. (2018). Cross-docking centre location in a supply chain network: A social network analysis approach. Global Business Review, 19(3_suppl), pp. S218-S234.

Basu, R., Guin, K.K. and Sengupta, K. (2014). Do apparel store formats matter to Indian shoppers?. International Journal of Retail \& Distribution Management, 42(8), pp.698-716.

Bloemer, J. and De Ruyter, K. (1998). On the relationship between store image, store satisfaction and store loyalty. European Journal of Marketing,32(5/6), pp.499-513.

Carpenter, J.M. and Moore, M. (2006). Consumer demographics, store attributes, and retail format choice in the US grocery market. International Journal of Retail \& Distribution Management, 34(6), pp.434-452.

Chang, H.J., Cho, H.J., Turner, T., Gupta, M. and Watchravesringkan, K. (2015). Effects of store attributes on retail patronage behaviors. Journal of Fashion Marketing and Management, 19(2), pp.136-153.

Das, G. (2014). Linkages of retailer awareness, retailer association, retailer perceived quality and retailer loyalty with purchase intention: A study of Indian food retail brands. Journal of Retailing and Consumer Services, 21(3), pp.284-292.

Daultani, Y., Goswami, M., Vaidya, O.S. and Kumar, S. (2019). Inclusive risk modeling for manufacturing firms: a Bayesian network approach. Journal of Intelligent Manufacturing, 30(8), pp.2789-2803.

Daultani, Y., Kumar, S. and Vaidya, O.S. (2016). Improving out-patient flow at an Indian ophthalmic hospital. Operations and Supply Chain Management, 9(1), pp.15-21.

Desai, K.K. and Talukdar, D. (2003). Relationship between product groups' price perceptions, shopper's basket size, and grocery store's overall store price image. Psychology \& Marketing, 20(10), pp.903-933.

Dhar, S.K. and Hoch, S.J. (1997). Why store brand penetration varies by retailer. Marketing Science, 16(3), pp.208-227.

Dhar, S.K., Hoch, S.J. and Kumar, N. (2001). Effective category management depends on the role of the category. Journal of Retailing, 77(2), pp.165-184.

Fullerton, G. (2005). The impact of brand commitment on loyalty to retail service brands. Canadian Journal of Administrative Sciences, 22(2), pp.97-110.

Fullerton, G. and Taylor, S. (2002). Mediating, interactive, and non-linear effects in service quality and satisfaction with services research. Canadian Journal of Administrative Sciences, 19(2), pp.124-136.

Ghosh, P., Tripathi, V. and Kumar, A. (2010). Customer expectations of store attributes: A study of organized retail outlets in India. Journal of Retail \& Leisure Property, 9(1), pp.75-87.

Huddiniah, E.R. and Mahendrawathi, E.R. (2019). Product Variety, Supply Chain Complexity and the Needs for Information Technology: A Framework Based on Literature Review. Operations and Supply Chain Management, 12(4), pp.245-255. 
Indian Gems and Jewellery Industry Report (October, 2019). ibef.org: Retrieved 26 Jan 2020, from https://www.ibef.org/industry/gems-jewelleryindia.aspx

Jani, D. and Han, H. (2014). Testing the moderation effect of hotel ambience on the relationships among social comparison, affect, satisfaction, and behavioral intentions. Journal of Travel \& Tourism Marketing, 31(6), pp.731-746.

Jhamb, D., \& Kiran, R. (2012). Emerging Retail Formats and its attributes: An insight to convenient shopping. Global Journal of Management and Business Research, 12(2), pp.63-71.

Kandulapati, S., \& Bellamkonda, R. (2014). Examining the structural relationships of service recovery, customer satisfaction and image in online retailing. Operations and Supply Chain Management: An International Journal, 7(2), pp.70-78

Koo, D. M. (2003). Inter-relationships among store images, store satisfaction, and store loyalty among Korea discount retail patrons. Asia Pacific Journal of Marketing and Logistics, 15(4), pp.42-71.

Krishnan, G.A. (2019). Women's desirability towards branded retail outlets with special reference to gold jewellery. ZENITH International Journal of Multidisciplinary Research, 9(7), pp.1-10.

Maheswari, R. and Balaji, K. (2017). A study on retail store image attributes and its formation for organized gem and jewellery retail outlet with reference to Pondicherry. South Asian Journal of Marketing \& Management Research, 7(9), pp.30-40.

Mittal, V., Huppertz, J.W. and Khare, A. (2008). Customer complaining: the role of tie strength and information control. Journal of Retailing, 84(2), pp.195-204.

Nair, S.R. (2018). Analyzing the relationship between store attributes, satisfaction, patronage-intention and lifestyle in food and grocery store choice behavior. International Journal of Retail \& Distribution Management, 46(1), pp.70-89.

Noronha, M. (2009). CRM and Value Chain Management in Jewellery Retail A Study of the Consumer's Perspective in Pune City. The Indian Journal of Commerce, 62(2), pp.67-70.

Pan, Y. and Zinkhan, G.M. (2006). Determinants of retail patronage: a meta-analytical perspective. Journal of Retailing, 82(3), pp.229-243.

Patel, B.S. and Desai, A.K. (2013). Factors affecting customer satisfaction in organized retail stores: a study of Surat city. Indian Journal of Applied Research, 3(5), pp.106-108.

Prajapati, D., Harish, A.R., Daultani, Y., Singh, H. and Pratap, S. (2020). A Clustering Based Routing Heuristic for Last-Mile Logistics in Fresh Food ECommerce. Global Business Review, doi.0972150919889797.

Prasad, C.J. and Aryasri, A.R. (2011). Effect of shopper attributes on retail format choice behaviour for food and grocery retailing in India. International Journal of Retail \& Distribution Management, 39(1), pp.68-86.

Rai, M. and Gopal, R. (2017). A study on the purchase behaviour of Indian women when buying diamond jewellery from different retail formats. IOSR Journal of Business and Management, 3, pp.1-7.

Ramanathan, U., Subramanian, N. and Parrott, G. (2017). Role of social media in retail network operations and marketing to enhance customer satisfaction. International Journal of Operations \& Production Management, 37(1), pp.105-123.

Ranjbari, M., Ahmadi, M., Gholam, A. and Shirzad, S. (2015). Relationship between Salespeople's Interactive Behavior towards Customers and Customer Loyalty. International Journal of Economy, Management and Social Sciences, 4(2), pp.182-187.

Schiffman, L.G., Kanuk, L.L. and Wisenblit, J. (2000). Consumer Behavior. Upper Saddle River. J: Prentice Hall.

Seock, Y.K. and Bailey, L.R. (2009). Fashion promotions in the Hispanic market. International Journal of Retail \& Distribution Management, 37(2), pp.161-181.

Shi, W., Tang, L., Zhang, X., Gao, Y. and Zhu, Y. (2016). How does word of mouth affect customer satisfaction? Journal of Business \& Industrial Marketing, 31(3), pp.393-403.

Sinha, P.K. and Banerjee, A. (2004). Store choice behaviour in an evolving market. International Journal of Retail \& Distribution Management, 32(10), pp.482-494.

Sivadas, E. and Baker-Prewitt, J.L. (2000). An examination of the relationship between service quality, customer satisfaction, and store loyalty. International Journal of Retail \& Distribution Management, 28(2), pp.73-82.

Söderlund, M., Berg, H. and Ringbo, J. (2014). When the customer has left the store: An examination of the potential for satisfaction rub-off effects and purchase versus no purchase implications. Journal of Retailing and Consumer Services, 21(4), pp.529-536.

Thomas, S. (2013). Linking customer loyalty to customer satisfaction and store image: a structural model for retail stores. Decision, 40(1-2), pp.15-25.

Truong, N., Dang-Pham, D., McClelland, R., \& Nkhoma, M. (2020). Exploring the Impact of Innovativeness of Hospitality Service Operation on Customer Satisfaction. Operations and Supply Chain Management: An International Journal, 13(3), pp.307-319.

Uvet, H. (2020). Importance of Logistics Service Quality in Customer Satisfaction: An Empirical Study. Operations and Supply Chain Management: An International Journal, 13(1), pp.1-10.

Venkatesh, P. (2015). An Empirical Study of Logistics Strategy for Service Quality at Retail Malls at Thane City and Suburban Mumbai in India. Operations and Supply Chain Management: An International Journal, 8(3), pp.128-136.

Yi, Y. and La, S. (2004). What influences the relationship between customer satisfaction and repurchase intention? Investigating the effects of adjusted expectations and customer loyalty. Psychology \& Marketing, 21(5), pp.351-373.

Yuen, E.F. and Chan, S.S. (2010). The effect of retail service quality and product quality on customer loyalty. Journal of Database Marketing \& Customer Strategy Management, 17(3-4), pp.222-240 
Dr. Yash Daultani is currently working as an Assistant Professor in Operations Management Group at Indian Institute of Management (IIM) Lucknow, India. His current academic interests comprise contemporary issues in operations and supply chain management. On the research front, his interests span over various areas like supply chain modeling, healthcare service operations, and operations research applications in production, transport, and logistics systems.

Kshitij Goyal has completed his Master of Business Administration (MBA) from Atal Bihari Vajpayee - Indian Institute of Information Technology and Management (ABV-IIITM) Gwalior, India. He is currently working as a Partner in Kalicharan Darshanlal Jewellers Gwalior - a franchisee of Birla Jewels Limited.

Dr. Saurabh Pratap is currently working as an Assistant Professor in the Department of Mechanical Engineering, Indian Institute of Technology (BHU), Varanasi, U.P, India. Previously, He worked as a Assistant Professor at Indian Institute of Information Technology, Jabalpur, India from June 2017 to Nov 2020 and Postdoctoral Fellow in the Department of Industrial \& Manufacturing Systems Engineering at University of Hong Kong, Hong Kong from Oct 2016 to May 2017. He has completed his Ph.D. degree in Industrial \& Systems Engineering Department at IIT Kharagpur, India in 2016. He has authored several technical papers. His publications appeared in such journals as International Journal of Production Economics, International Journal of Production Research, Computers \& Industrial Engineering, Annals of Operation Research, Journal of Intelligent Manufacturing and Maritime Economics \& logistics. He carried out collaborative research with the Laboratory for production Management and Process in EPFL, Switzerland and University of Hong Kong, HK. He is working as a reviewer for 21 renowned International Journals. 